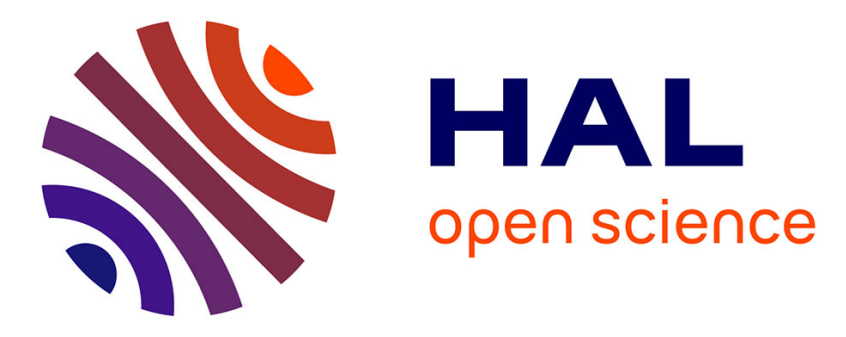

\title{
Zinc-Alpha-2-Glycoprotein in Inflammatory Bowel Disease
}

Véronique Rolli, Cécile Macquin, Tunay Kokten, Julie Hablot, Ndeye-Coumba

Ndiaye, Patrick Netter, Seiamak Bahram, Jean-Yves Jouzeau, Laurent

Peyrin-Biroulet, Philippe Georgel, et al.

\section{To cite this version:}

Véronique Rolli, Cécile Macquin, Tunay Kokten, Julie Hablot, Ndeye-Coumba Ndiaye, et al.. ZincAlpha-2-Glycoprotein in Inflammatory Bowel Disease. Inflammatory Bowel Diseases, 2018, 24 (5), pp.e10. 10.1093/ibd/izy120 . hal-02401061

\section{HAL Id: hal-02401061 \\ https://hal.science/hal-02401061}

Submitted on 9 Dec 2019

HAL is a multi-disciplinary open access archive for the deposit and dissemination of scientific research documents, whether they are published or not. The documents may come from teaching and research institutions in France or abroad, or from public or private research centers.
L'archive ouverte pluridisciplinaire HAL, est destinée au dépôt et à la diffusion de documents scientifiques de niveau recherche, publiés ou non, émanant des établissements d'enseignement et de recherche français ou étrangers, des laboratoires publics ou privés. 


\section{Zinc-Alpha-2-Glycoprotein in Inflammatory Bowel Disease}

\section{To the Editors,}

Zinc-Alpha-2-Glycoprotein (ZAG), a $40 \mathrm{kDa}$ soluble protein present in various body fluids (serum, urine, seminal fluid, saliva, and milk), controls adipose tissue mobilization in the context of cachexia. ${ }^{1-3}$ Inflammatory Bowel Diseases (IBD), including Crohn's disease (CD) and ulcerative colitis (UC), have been historically associated with cachexia and malnutrition. Furthermore, a recent connection between ZAG and Th17 lymphocyte, a subpopulation of adaptive immune cell involved in both mucosal homeostatic microbial protection and IBD occurring inflammation has been made, suggesting a vicious cycle worsening inflammation and metabolic disorder in systemic inflammatory disease. ${ }^{4}$ We thus explored the potential role of $\mathrm{ZAG}$ in IBD.

We first measured serum levels of ZAG using ELISA in IBD patients, UC $(\mathrm{n}=70)$ and $\operatorname{CD}(\mathrm{n}=109)$, enrolled in the "Nancy IBD cohort" and healthy controls $(\mathrm{n}=105)$. ZAG levels are significantly increased in patients with UC $(31,4 \pm 8 \mu \mathrm{g} / \mathrm{ml}$ vs $27,6 \pm 3,8 \mu \mathrm{g} / \mathrm{ml} ; P=0.0019)$, whereas no statistical difference is observed in patients with $\mathrm{CD}(28,2 \pm 6,5 \mu \mathrm{g} / \mathrm{ml})$ (Fig. 1A). This prompted us to look in the animal model of colitis. We thus induced dextran sodium sulfate (DSS) colitis in ZAG-/- mice ( $\mathrm{n}=12$ ) and wildtype animals $(\mathrm{n}=11)$. Severity of colitis, measured by disease activity score (Fig. 1B), daily fecal lipocalin2 dosage (not shown), and final histological examination (not shown) revealed no difference between wild-type and ZAG deficient mice.

\footnotetext{
Published online 23 April 2018 in academic.oup.com/ibdjournal

(C) 2018 Crohn's \& Colitis Foundation. Published by Oxford University Press.

All rights reserved. For permissions, please e-mail: journals.permissions@oup.com.
} doi: 10.1093/ibd/izy120

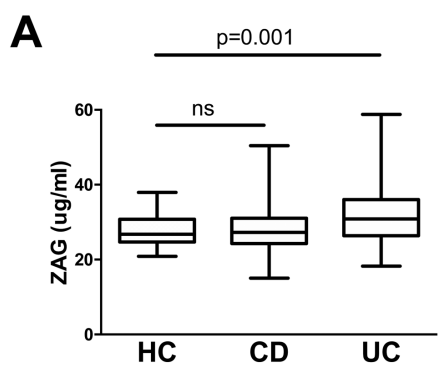

B

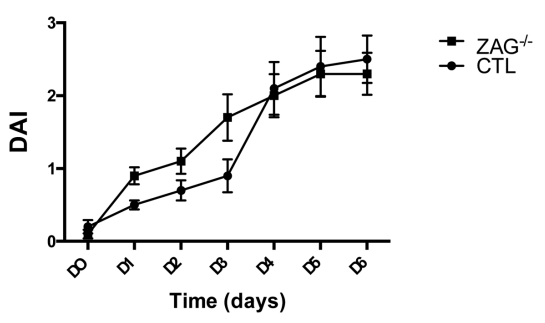

FIGURE 1. A, ZAG protein level is elevated in UC patients. Plasmatic levels of ZAG were measured by ELISA in UC $(n=70), C D(n=109)$, and healthy controls $(n=105)$. B, DSS occurrence and severity is not altered in ZAG deficient mice. DSS Colitis was induced by administration of $3 \%$ DSS (Colitis grade MW 36-50kDa) (MPBiomedicals) in drinking water for 6 days in control and ZAG deficient mice. Daily, the severity of colitis was evaluated by the disease activity index (DAI). The DAl was calculated with the body weight loss $(0=$ no weight loss, $1=0 \%-5 \%$ weight loss, $2=5 \%-10 \%$ weight loss, $3=10 \%-20 \%$ weight loss, $4=$ more than $20 \%$ weight loss); feces consistency $(0=$ normal, $2=$ loose stools, $4=$ diarrhea); and the presence of blood in the feces $(0=$ negative, 2 = positive, $4=$ important presence of blood in the feces).

Taken together, these data suggest that ZAG might only reflect inflammation occurring in patients with UC, as animal data are not in favor of a direct role in IBD pathophysiology.

\section{Véronique Rolli, PhD, * Cécile Macquin, MSc, * Tunay Kokten, PhD, ${ }^{\dagger}$ Julie Hablot, MSc,} Ndeye-Coumba Ndiaye, $\mathrm{PhD},{ }^{\dagger}$ Patrick Netter, MD, PhD, * Seiamak Bahram, MD, PhD, * Jean-Yves Jouzeau, PharmD, PhD, ${ }^{*}$ Laurent Peyrin-Biroulet, MD, PhD, ${ }^{\dagger}$ Philippe Georgel, PhD, *, and David Moulin, $\mathrm{PhD}^{ \pm, \&, \oplus}$

*Immunorhumatologie Moléculaire, UMR_S 1109, Strasbourg, France; ${ }^{\top}$ NGERE, UMR_ S954 INSERM-Université de Lorraine, Vandœuvre Les Nancy, France;

†IMoPA, UMR7365 CNRS-Université de Lorraine, Vandœuvre Les Nancy,
France; ${ }^{\S} \mathrm{CHRU}$ de Nancy, Contrat d'interface, Vandœuvre Les Nancy, France

Supported by: This work was supported partly by the French PIA project "Lorraine Université d'Excellence ", reference ANR-15-IDEX-04-LUE; INSERM UMR_S 1109 and Institut Universitaire de France. TThese authors contributed equally to this work.

Conflicts of Interest: Authors have no conflict of interest to declare.

Address correspondence to: Philippe Georgel, $\mathrm{PhD}$, ImmunoRhumatologie Moléculaire, INSERM UMR_S 1109 Université de Strasbourg, Centre de Recherche d'Immunologie et d'Hématologie, 1 Place de l'Hopital, 67085 Strasbourg France. E-mail: pgeorgel@unistra.fr

\section{REFERENCES}

1. Hassan MI, Waheed A, Yadav S, et al. Zinc alpha 2-glycoprotein: a multidisciplinary protein. $\mathrm{Mol}$ Cancer Res. 2008;6:892-906.

2. Rolli V, Radosavljevic M, Astier V, et al. Lipolysis is altered in MHC class I zinc-alpha(2)-glycoprotein deficient mice. FEBS Lett. 2007;581:394-400.

3. Balaz M, Ukropcova B, Kurdiova $\mathrm{T}$, et al. Adipokine zinc- $\alpha 2$-glycoprotein regulated by growth hormone and linked to insulin sensitivity. Obesity (Silver Spring). 2015;23:322-8.

4. Na HS, Kwon JE, Lee SH, et al. Th17 and IL-17 cause acceleration of inflammation and fat loss by inducing $\alpha 2$-glycoprotein 1 (AZGP1) in rheumatoid arthritis with high-fat diet. Am J Pathol. 2017; 187:1049-58. 